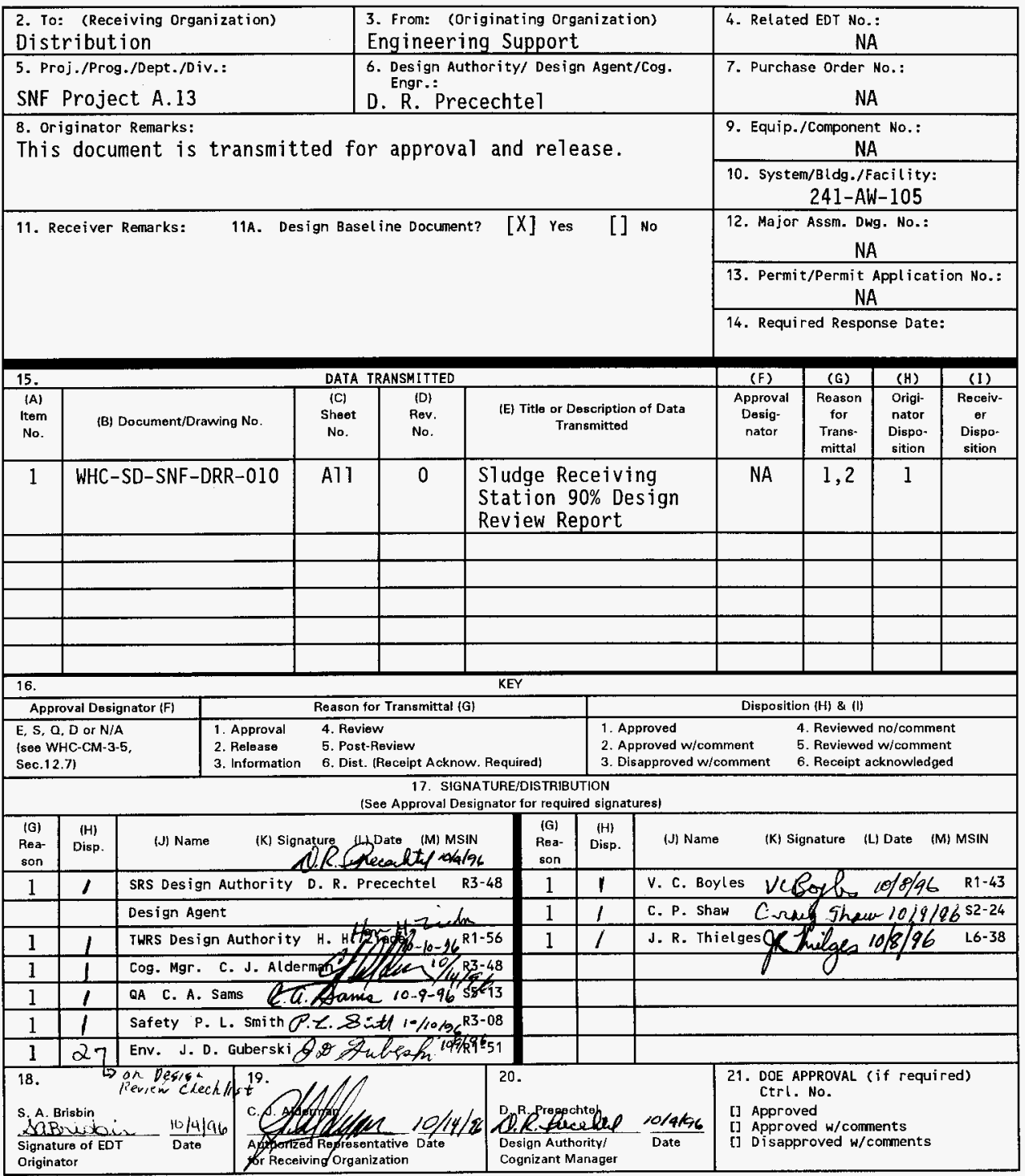

BD-7400-172-2 (05/96) GEF097 


\title{
Sludge Receiving Station 90\% Design Review Report
}

\author{
S. A. Brisbin
}

DE\&S Hanford, Richland, WA 99352

U.S. Department of Energy Contract DE-AC06-87RL10930

$\begin{array}{lll}\text { EDT/ECN: } & 619350 & \text { UC: } 600 \\ \text { Org Code: } 2 C 500 & \text { Charge Code: LD089 } \\ \text { B\&R Code: } & \text { EW3135040 } & \text { Total Pages: } 3152 \text { fand } 10 / 14 / 46\end{array}$

Key Words: Sludge Receiving Station, TWRS, AW Tank Farm, design review

Abstract: The Sludge Receiving Station will be used to directly transfer $K$ Basins sludge from the Sludge Transportation System into double-she11 tank 214-AW-105.

TRADEMARK DISCLAIMER. Reference herein to any specific commercial product, process, or service by trade name, trademark, manufacturer, or otherwise, does not necessarily constitute or imply its endorsement, reconmendation, or favoring by the United States Government or any agency thereof or its contractors or subcontractors.

Printed in the United States of America. To obtain copies of this document, contact: WHC/BCS Document Control Services, P.O. Box 1970, Mailstop H6-08, Richland WA 99352, Phone (509) 372-2420; Fax (509) $376-4989$.
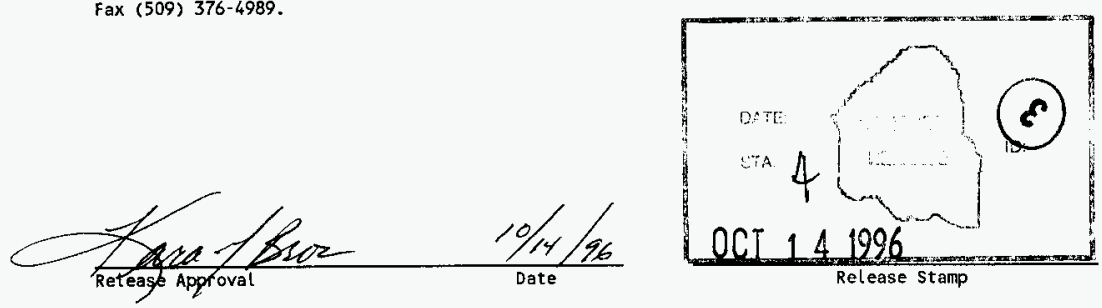
WHC-SD-SNF-DRR-010, Rev. 0

CONTENTS

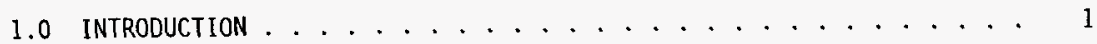

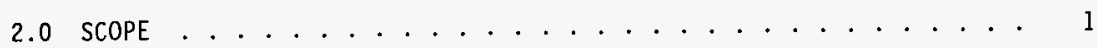

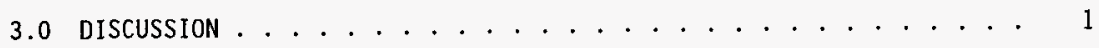

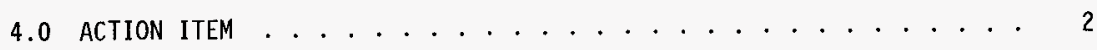

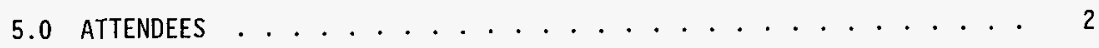

APPENDIX A-MEETING MinUTES . . . . . . . . . . . . . A-1

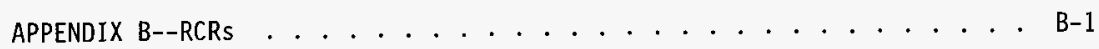

APPENDIX C--DESIGN REVIEW CHECKLIST .............. C-1 
WHC-SD-SNF-DRR-010, Rev. 0

\section{SLUDGE RECEIVING STATION 90\% DESIGN REVIEW REPORT}

\subsection{INTRODUCTION}

The Sludge Receiving Station will be used to directly transfer K Basins sludge from a Sludge Transportation System into a selected double-shell tank (DST). Current baseline is that the selected DST wi11 be 241-AW-105. The Sludge Receiving Station consists of a nonpermanent, intra-farm transfer line (with double containment), a pipe jumper inside the pump pit connecting the transfer 1 ine to an existing DST riser, and a spill retention basin.

\subsection{SCOPE}

The scope of this review was to verify that the Sludge Receiving Station design conforms to the functional design criteria and that the assumptions used for the seismic/structural analys is were correct.

\subsection{DISCUSSION}

Jim Thielges, Design Review Chairman, opened the meeting. Following the opening remarks, the meeting was turned over to Sherri Brisbin. Sherri asked if there were any comments on the minutes from the September 12, 1996, design review briefing. No one had any comments. Meeting minutes are provided in Appendix A. Sherri then began a discussion of the review comment records (RCRs) received to date. The RCR comments were tentatively dispositioned by acceptance, rejection, or identification of further actions to close the comment. Dispositioned RCRs are provided in Appendix B.

Because neither the safety assessment nor the structural/seismic analysis is complete, it was suggested that this is not a 90 percent design review. Initially, agreement was made to redefine the completion percentage. Although all analyses are not complete, draft analyses have been prepared in conjunction with the design and the design is based on similar designs that have been implemented in the past. Further review with SNF Project management led to a decision to maintain the initial completion percentage, 90 percent. There is some risk associated with that decision; however, the SNF Project feels that the risk is manageable.

During discussion of comments, Vic Boyles indicated that the current schedule (1 year or less for transfer of all sludge into the DST) is very aggressive from a Tank Waste Remediation System perspective.

Following comment resolution, Jim Thielges led a discussion of the design review checklist. The completed checklist is provided in Appendix C. 


\subsection{ACTION ITEM}

Provide DRAFT Structural Analysis for review in early October 1996. Actionee: Dennis Crass/Ann Wellner.

\subsection{ATTENDEES}

Meeting attendees were:

\begin{tabular}{|c|c|c|}
\hline Name & Phone & Organization/Function \\
\hline C. J. Alderman & $376-1796$ & SNF Engineering Support \\
\hline${ }^{*}$ V. C. Boyles & $373-1321$ & TWRS Evaporator Project \\
\hline S. A. Brisbin & $376-9180$ & SNF Engineering Support \\
\hline D. B. Campbe11 & $376-8356$ & TWRS Design \\
\hline D. W. Crass & $372-2034$ & $\begin{array}{c}\text { Tank System Integration/ } \\
\text { Design Agent }\end{array}$ \\
\hline W. G. Farley & $376-9192$ & TWRS SAR Engineering \\
\hline K. L. Pearce & $376-3782$ & SNF Engineering Support \\
\hline J. E. Pieper & $376-4175$ & ETF Rad Con \\
\hline "D. R. Precechtel & $376-3329$ & $\begin{array}{c}\text { SNF Engineering Support/SRS } \\
\text { Design Authority }\end{array}$ \\
\hline${ }^{*}$ C. A. Sams & $376-9618$ & TWRS QA \\
\hline${ }^{*}$ C. P. Shaw & $376-0814$ & Equipment Engineering \\
\hline${ }^{*}$ P. L. Smith & $372-2471$ & TWRS Safety \\
\hline D. H. Splett & $373-7827$ & $\mathrm{RL}-\mathrm{SFD}$ \\
\hline *J. R. Thielges & $376-9029$ & Design Review Chairman \\
\hline W. W. Wassberg & $372-1958$ & Mactec \\
\hline A. F. Wellner & $372-1101$ & ICF KH Engineering/ Design Agent \\
\hline${ }^{*}$ H. H. Ziada & $376-0910$ & TWRS Design Authority \\
\hline
\end{tabular}


WHC-SD-SNF-DRR-010, Rev. 0

\section{APPENDIX A--MEETING MINUTES}

A-1 


\section{MEETING MINUTES \\ Design Review Briefing for the Sludge Receiving Station}

The design review briefing for the Sludge Receiving Station was held on September 12, 1996.

The attendees were:

Wendy Adams (for *Chuck Sams)
*Vic Boyles
Sherri Brisbin
*Kelly Carothers
Dennis Crass
Phil Daling
John Guberski
"Oscar M. Holgado
Mike McWethy
Frank W. Moore
Frank Muller
Kathleen Pearce
"Donald Precechtel
*Craig Shaw
*Peter L. Smith
*Dale Splett
*Jim Thielges

Shakir Zaman
TWRS QA Evaporator Project SNF/Engineering Support TWRS Design Authority Tank Systems Integration (Design Agent) PNNL

TWRS Environmental Compliance DOE-RL SFD

SNF/Engineering Support

SNF/K Basins Projects

SNF/K Basins Projects

SNF/Engineering Support SNF/Engineering Support (SRS Design Authority)

TWRS Equipment Engineering

TWRS Nuclear Safety

DOE-RL SFD

Equipment Development (Design Review Chairman)

TWRS Nuclear Safety

*Denotes member of Design Review Committee

Jim Thielges opened the meeting by welcoming attendees. The meeting attendees then introduced themselves. Jim then presented the briefing scope.

Sherri Brisbin described the design review package and explained the status of its contents. The design review committee was requested to review: the drawing tree, drawings, the approach for the seismic/structural analysis, the ALARA checklist, and the design review checklist. The design review checklist will be completed at the design review meeting. Reviewers were requested to provide RCR comments at the design review meeting, or sooner if possible. Sherri explained that under the current schedule, this project will be put "ON HOLD" until FY98. Therefore, it is desireable to incorporate as many comments as practical and issue the documentation in a form that is not acceptable for construction, but readily retrievable.

Dennis Crass described the Sludge Receiving Station and explained the changes that were made since the last review. Dennis indicated that concrete blocks may be required under the jack stands to meet seismic/structural requirements. Dennis indicated that we may be able to reduce or eliminate the shielding blocks following completion of the final seismic and shielding 


\section{MEETING MINUTES \\ Design Review Briefing for the Sludge Receiving Station}

analyses. Dennis recommended draining the flush hose following use in lieu of providing heat trace. Heat trace required for the Tength of hose being considered would have a significant current load.

Dennis also described the approach that was being used for the seismic/structural analysis. Dennis indicated that a draft structural analysis will be completed by the end of September.

A question was raised regarding the status of the air emmission calculations for the tank farm. Kathleen Pearce indicated that these calculations have not been initiated.

John Guberski indicated that there are two, one million gallon 1 iners available onsite if anyone is interested.

Don Precechte] asked what the impact of increasing the design life from the current 3 years to 5 or 10 years would be. Dennis crass indicated that no significant problems would be anticipated. However, a different material may be required for the inner hose. The spill retention basin is already a replaceable item.

The design review meeting will be scheduled for September 25, 1996 at 8:00 am at $2752 \mathrm{E} / \mathrm{C} 101$.

Action: Design Review Committee members are to have RCR comments to Sherri Brisbin as soon as possible, but no later than the September 25, 1996, design review meeting. 
WHC-SD-SNF-DRR-010, Rev, 0

APPENDIX B--RCRS 


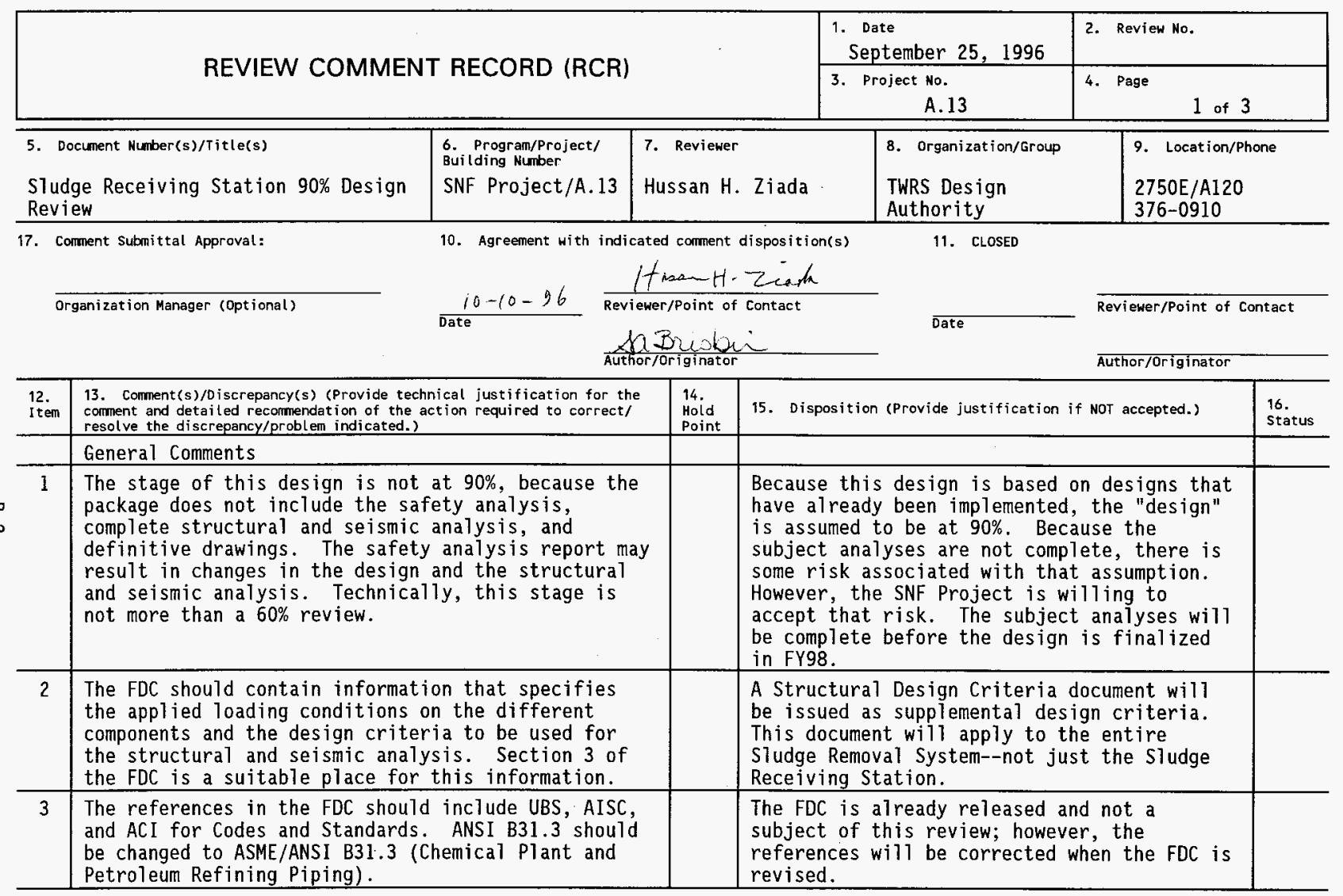




\begin{tabular}{|l|l|l|l|}
\hline \multirow{2}{*}{ REVIEW COMMENT RECORD (RCR) } & $\begin{array}{l}\text { 1. Date } \\
\text { September 25, } 1996\end{array}$ & Review No. \\
\cline { 2 - 4 } & $\begin{array}{r}3 . \text { Project No. } \\
\text { A.13 }\end{array}$ & $\begin{array}{l}4 . \text { Page } \\
2\end{array}$ \\
\hline
\end{tabular}

\begin{tabular}{|c|c|c|c|c|}
\hline $\begin{array}{l}12 . \\
\text { it tem }\end{array}$ & $\begin{array}{l}\text { 13. Comment(s)/Discrepancy(s) (Provide technical justification for the } \\
\text { comment and detai led recommendation of the action required to correct/ } \\
\text { resolve the discrepancy/problem indicated.) }\end{array}$ & $\begin{array}{l}14 \text { id } \\
\text { Hold } \\
\text { Point }\end{array}$ & 15. Disposition (Provide justification if NOT accepted.) & $\begin{array}{l}16 . \\
\text { Status } \\
\end{array}$ \\
\hline 4 & $\begin{array}{l}\text { The FDC does not include information on the sludge } \\
\text { characteristics (e.g., sludge concentration, maximum } \\
\text { particle size, etc.). This was accepted to be in } \\
\text { Section } 3 \text { per Item } 1 \text { il of the RCR provided by Hassan } \\
\text { Ziada. }\end{array}$ & & $\begin{array}{l}\text { The FDC was extensively revised since the } \\
\text { last review. The required information is } \\
\text { reference in Section } 2.2 \text {. }\end{array}$ & \\
\hline 5 & Page 16 of the $F D C$ is missing. & & $\begin{array}{l}\text { This page was lost during duplicating. Page } \\
16 \text { was provided at the design review. }\end{array}$ & \\
\hline \multirow[t]{2}{*}{6} & $\begin{array}{l}\text { In the Dose Rate Calculations, the units in the } \\
\text { tables are not consistent, some are } 18^{\prime \prime} \text { and } 48^{\prime \prime} \text { and } \\
\text { others are } 0.5 \mathrm{~m} \text { and } 1.0 \mathrm{~m} \text {. }\end{array}$ & & $\begin{array}{l}\text { Comment noted. This document has already } \\
\text { been issued and is not part of the formal } \\
\text { review. }\end{array}$ & \\
\hline & Drawing Tree and Design Drawings & & & \\
\hline 1 & $\begin{array}{l}\text { Drawing H-14-100727 is not included in the } 1 \text { ist of } \\
\text { drawings (upper left corner) in the Drawing Tree. }\end{array}$ & & Drawing will be revised as necessary. & \\
\hline 2 & $\begin{array}{l}\text { The number of sheets of some drawings in the Drawing } \\
\text { Tree does not match with the Design Drawings } \\
\text { (Drawings 100776, 100777, 100780,100781, and } \\
100783 \text { ). }\end{array}$ & & Drawing(s) will be revised as necessary. & \\
\hline 3 & $\begin{array}{l}\text { Add the word "DETAILS" at the end of the title of } \\
\text { drawing } H-14-100788 \text { in the Drawing Tree. }\end{array}$ & & Accept. & \\
\hline 4 & $\begin{array}{l}\text { The two missing drawings }(H-14-X X X X X X) \text { need to be } \\
\text { provided before the end of the fiscal year. }\end{array}$ & & $\begin{array}{l}\text { Not accepted. These drawings may not be } \\
\text { needed at a11. Regardless, these drawings } \\
\text { will not be completed in FY96. }\end{array}$ & \\
\hline \multirow[t]{2}{*}{5} & $\begin{array}{l}\text { The title of drawing } \mathrm{H}-14-100788 \text { is not consistent } \\
\text { on both sheets and to the title on the Drawing Tree. }\end{array}$ & & $\begin{array}{l}\text { Drawing titles will be corrected as } \\
\text { necessary. }\end{array}$ & \\
\hline & Seismic/Structural Analysis & & & \\
\hline 1 & $\begin{array}{l}\text { The piping analysis should consider seismic, } \\
\text { pressure, dead weight, and temperature loading. }\end{array}$ & & Accept. & \\
\hline 2 & $\begin{array}{l}\text { The pit (or riser) should be analyzed for the } \\
\text { interface loads imposed by the mounted jumper and } \\
\text { distributer. }\end{array}$ & & $\begin{array}{l}\text { We will verify that this is bounded by the } \\
\text { existing analysis. If not, we will update } \\
\text { the existing analysis. }\end{array}$ & \\
\hline
\end{tabular}




\begin{tabular}{|l|l|l|}
\hline \multirow{2}{*}{ REVIEW COMMENT RECORD (RCR) } & $\begin{array}{l}\text { 1. Date } \\
\text { September 25, } 1996\end{array}$ & 2. Review No. \\
\cline { 2 - 4 } & $\begin{array}{c}3 . \text { Project No. } \\
\text { A.13 }\end{array}$ & 4. Page \\
\hline
\end{tabular}

\begin{tabular}{|c|c|c|c|c|}
\hline $\begin{array}{l}12 . \\
\text { Item }\end{array}$ & $\begin{array}{l}\text { 13. Comment(s)/Discrepancy(s) (Provide technical justification for the } \\
\text { comment and detailed recommendation of the action required to correct/ } \\
\text { resolve the discrepancy/problem indicated.) }\end{array}$ & $\begin{array}{l}14 . \\
\text { Hoid } \\
\text { Point }\end{array}$ & 15. Disposition (Provide justification if NOT accepted.) & $\begin{array}{l}16 . \\
\text { status }\end{array}$ \\
\hline 3 & $\begin{array}{l}\text { The Spill Retention Basin although it is off-the- } \\
\text { shelf item, needs to be analyzed and qual ified for } \\
\text { seismic loading, either by the vendor of end user. }\end{array}$ & & $\begin{array}{l}\text { Need will be verified following completion } \\
\text { of the safety assessment. }\end{array}$ & \\
\hline 4 & $\begin{array}{l}\text { The Offload Platform (Support Stand) should be } \\
\text { analyzed for wind loads, and vibrations and drop } \\
\text { loads (if any). }\end{array}$ & & $\begin{array}{l}\text { These will be evaluated to determine which } \\
\text { are apply and analyzed accordingly. }\end{array}$ & \\
\hline 5 & $\begin{array}{l}\text { After the safety report is completed, the analysis } \\
\text { should be revised in accordance with the specified } \\
\text { safety class. }\end{array}$ & & Accept. & \\
\hline
\end{tabular}

co

$+$ 


\begin{tabular}{|l|l|l|}
\hline \multirow{2}{*}{ REVIEW COMMENT RECORD (RCR) } & $\begin{array}{l}\text { 1. Date Review No. } \\
9 / 26 / 96\end{array}$ & \multicolumn{2}{|c|}{1} \\
\cline { 2 - 4 } & 3. Project No. Page & \\
\hline
\end{tabular}

\begin{tabular}{l|l|l|l|l}
\hline 5. Document Number(s)/ritle(s) & $\begin{array}{l}\text { 6. Program/Project/ } \\
\text { Building Number } \\
\text { SNF Project - } \\
\text { K-Basins 90\% Conceptual Design } \\
\text { Review }\end{array}$ & $\begin{array}{l}\text { Sludge Offload } \\
\text { Station }\end{array}$ & 8. D. Guberski & $\begin{array}{l}\text { TFTP Enviration/Group } \\
\text { Compiance \& Support } \\
\text { Services }\end{array}$ \\
\hline
\end{tabular}

17. Comment Submittal Approval:

Organization Manager (Optional)
10. Agreement with indicated comment disposition(s)

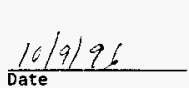

tith 2 Gubech
11. CLOSED

$\overline{\text { Date }}$ Reviewer/Point of Contact

Author/Originator

\begin{tabular}{|c|c|c|c|c|}
\hline $\begin{array}{l}12 . \\
\text { I tem }\end{array}$ & $\begin{array}{l}\text { 13. Comment(s)/Discrepancy(s) (Provide technical justification for the } \\
\text { comment and detailed recomendation of the action required to correct/ } \\
\text { resolve the discrepancy/problem indicated.) }\end{array}$ & $\begin{array}{l}14 . \\
\text { Hold } \\
\text { Point }\end{array}$ & 15. Disposition (Provide justification if NOT accepted.) & $\begin{array}{l}16 . \\
\text { Status }\end{array}$ \\
\hline 1 & $\begin{array}{l}\text { Drawing } \mathrm{H}-14-100776 \text {, sheet } 2 \text {, North arrow points } \\
\text { East }\end{array}$ & & Arrow will be corrected. & \\
\hline 2 & $\begin{array}{l}\text { Drawing } \mathrm{H}-14-100776 \text {, sheet } 4 \text {, Ball valve, item } 60 \text {, } \\
\text { needs to be rotated so handle is on south side of } \\
\text { piping. Operations \& Maintenance need to access } \\
\text { valve. This is difficult as orientated. }\end{array}$ & Yes & $\begin{array}{l}\text { Change will be evaluated and updated as } \\
\text { necessary. }\end{array}$ & \\
\hline 3 & $\begin{array}{l}\text { Drawing } \mathrm{H}-14-100776 \text {, sheet } 4 \text {, leak detector, items } \\
39,40 \& 64 \text {, need to be rotated so leak detector is } \\
\text { on south or south-east side of piping. Maintenance } \\
\text { needs to be able to remove leak detector for } \\
\text { maintenance and calibration. This is difficult as } \\
\text { orientated. }\end{array}$ & Yes & $\begin{array}{l}\text { Change will be evaluated and updated as } \\
\text { necessary. }\end{array}$ & \\
\hline 4 & $\begin{array}{l}\text { Drawing } \mathrm{H}-14-100776 \text {, sheet } 6 \text {, recommend rotating } \\
\text { leak detector and ball valve so they can be accessed } \\
\text { through cover block cut out for operation or } \\
\text { maintenance. Consider enlargement of cutout to } \\
\text { allow for this if current opening is to small. }\end{array}$ & No & $\begin{array}{l}\text { Recommendation will be considered; however, } \\
\text { initial seismic/structural analys is has been } \\
\text { performed and a larger hole may have a } \\
\text { significant impact. }\end{array}$ & \\
\hline
\end{tabular}




\begin{tabular}{|l|l|l|l|}
\hline \multirow{2}{*}{ REVIEW COMMENT RECORD (RCR) } & 1. Date Review No. & $9 / 26 / 96$ & \multicolumn{2}{|c|}{1} \\
\cline { 2 - 3 } & 3. Project No. & 4. Page \\
\hline
\end{tabular}

\begin{tabular}{c|l|l|l|l}
\hline $\begin{array}{l}\text { 12. } \\
\text { Item }\end{array}$ & $\begin{array}{l}\text { 13. Comment(s)/Discrepancy(s) (Provide technical justification for the } \\
\text { coment and detailed recommenation of the action required to correct/ } \\
\text { resolve the discrepanc/problem indicated.) }\end{array}$ & $\begin{array}{l}\text { 14. } \\
\text { Hoid } \\
\text { Point }\end{array}$ & 15. Disposition (Provide justification if Nor accepted.) \\
\hline 5 & $\begin{array}{l}\text { The soon to be issued Tank Farms Basis for Interim } \\
\text { Operation [BI0] document limits fuel capacity of } \\
\text { vehicles to <60 gallons if vehicle fuel tank or fuel } \\
\text { iines are at same height or lower than a riser that } \\
\text { connects to tank. This may be applicable to } \\
\text { transport vehicle. }\end{array}$ & No & $\begin{array}{l}\text { Comment noted. This should not impact the } \\
\text { design of the transport system, but it may } \\
\text { impose administrative constraints on the } \\
\text { tractor before it can enter the tank farm. }\end{array}$ & \\
\hline & & & \\
\hline
\end{tabular}

0
1
$a$ 


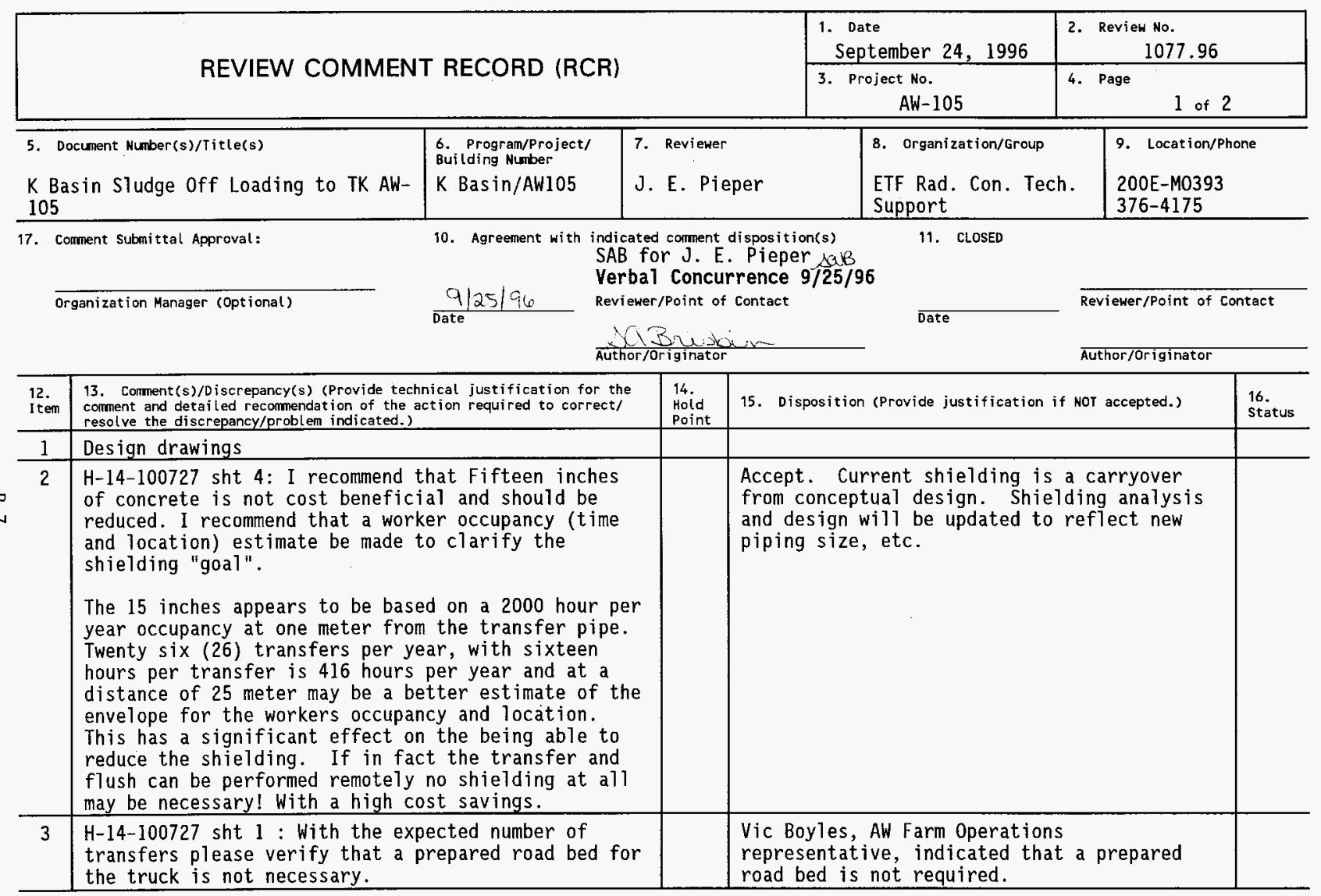




\begin{tabular}{|l|l|l|}
\hline \multirow{2}{*}{ REVIEW COMMENT RECORD (RCR) } & $\begin{array}{l}\text { 1. Date } \\
\text { September 24, } 1996\end{array}$ & $\begin{array}{c}2 . \text { Review No. } \\
1077.96\end{array}$ \\
\cline { 2 - 3 } & $\begin{array}{c}3 . \text { Project No. } \\
\text { AW-105 }\end{array}$ & $\begin{array}{l}4 . \text { Page } \\
2 \text { of } 2\end{array}$ \\
\hline
\end{tabular}

\begin{tabular}{|c|c|c|c|c|}
\hline $\begin{array}{l}12 . \\
1 \text { tem }\end{array}$ & $\begin{array}{l}\text { 13. Comment(s)/Discrepancy(s) (Provide technical justification for the } \\
\text { comment and detailed recommendation of the action required to correct/ } \\
\text { resolve the discrepancy/problem indicated.) }\end{array}$ & $\begin{array}{l}14 . \\
\text { Hoid } \\
\text { Point }\end{array}$ & 15. Disposition (Provide justification if NOT accepted.) & $\begin{array}{l}16 . \\
\text { status }\end{array}$ \\
\hline 4 & $\begin{array}{l}\text { H-14-100727 sht } 1 \text { : Even though a "dry disconnect" } \\
\text { might work properly, I recommend a stainless steel } \\
\text { pan under each connection. }\end{array}$ & & Accept. & \\
\hline 5 & $\begin{array}{l}\text { H-14- } 100727 \text { sht } 1 \text { : The " } 3 \text { " DBL CHECK VALVE" under } \\
\text { the truck bed shown at E-5 may just be a crud } \\
\text { collector and not of value. A ball valve with a } \\
\text { extension handle may work better. }\end{array}$ & & $\begin{array}{l}\text { This valve is part of the Sludge } \\
\text { Transportation System. We do not have a } \\
\text { design for that system yet. The comment } \\
\text { will be retained and evaluated during design } \\
\text { of the sludge Transportation System. }\end{array}$ & \\
\hline 6 & $\begin{array}{l}\text { H-14-100727 sht } 1 \text { : Please review whether the hose } \\
\text { under the truck may require support to prevent } \\
\text { "sagging" and unnecessarily collecting siudge. }\end{array}$ & & $\begin{array}{l}\text { This is part of the Sludge Transportation } \\
\text { System. See disposition \#5. }\end{array}$ & \\
\hline 7 & $\begin{array}{l}\text { H-14-100781 part } 10 \text {, subassembly, jumper : please } \\
\text { verify that this eight foot long " } L " \text { shaped jumper } \\
\text { does not require an additional support in the middle } \\
\text { (from the floor of the pit) to allow proper } \\
\text { connection and prevent sagging. }\end{array}$ & & Accept. & \\
\hline 8 & $\begin{array}{l}\text { H-14-100727, C-7: I recommend that the "VALVE SHUT } \\
\text { OFF" on the truck have a horizontal collector } \\
\text { handle, so that it may be easily shut of by } \\
\text { personnel on the ground beside the truck (from the } \\
\text { side opposite the transfer line). }\end{array}$ & & See disposition \#6. & \\
\hline 9 & $\begin{array}{l}\text { ALARA Design Review Check List : I recommend that } \\
\text { this form be filled out with the expectations of the } \\
\text { design and best estimates. This would have been } \\
\text { useful in the quantification of the amount of } \\
\text { shielding necessary. Since it leads you to estimate } \\
\text { the time, distance and number of personnel. }\end{array}$ & & Accept. ALARA checklist will be updated. & \\
\hline
\end{tabular}




\begin{tabular}{|c|c|c|}
\hline & $\begin{array}{l}\text { 1. Date } \\
09 / 23 / 96 \\
\end{array}$ & $\begin{array}{r}\text { 2. Review No. } \\
2 \\
\end{array}$ \\
\hline REVIEV COMMEN I RECORD (RCK) & $\begin{array}{l}\text { 3. Project No. } \\
\text { A. } 13\end{array}$ & 4. Page \\
\hline
\end{tabular}

5. Document Number(s)/Title(s)

WHC-SD-SNF-CDR-008, Rev.0 Conc. Des. Report for Siudge Receiving Station

17. Comment Submittal Approval:

Organization Manager (Optional)

\begin{tabular}{l|l}
$\begin{array}{l}\text { 6. Program/Project/ } \\
\text { Building Number }\end{array}$ & 7. Reviewer \\
Spent Nuclear & V. C. Boyles \\
Fuels/Proj.A.13/ & AW
\end{tabular}

10. Agreement with indicated comment disposition(s)
8. Organization/Group

Evaporator Project
9. Location/Phone

2750E/373-1321

11. CLOSED

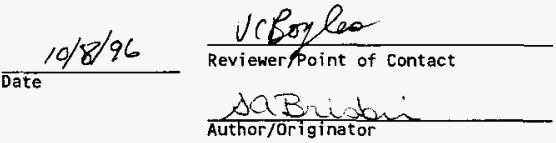

\section{Date}

Reviewer/Point of Contact

\begin{tabular}{|c|c|c|c|c|}
\hline $\begin{array}{l}12 . \\
\text { I tem }\end{array}$ & $\begin{array}{l}\text { 13. Comment }(s) / D i s c r e p a n c y(s) \text { (Provide technical justification for the } \\
\text { comment and detailed recomnendation of the action required to correct/ } \\
\text { resolve the discrepancy/problem indicated.) }\end{array}$ & $\begin{array}{l}14 . \text { id } \\
\text { Hold } \\
\text { Point }\end{array}$ & 15. Disposition (Provide justification if NOT accepted.) & $\begin{array}{l}16 . \\
\text { Status }\end{array}$ \\
\hline 1 & $\begin{array}{l}\text { On CDR-008///Page } 2 \text {, sec. } 2.0 \text { says } 1 / 2000 \text { to } 12 / 2000 \text {. } \\
\text { But WHC-SD-SNF-020, Rev. } 0 \text { Says } 11 / 97 \text { and DOE's press } \\
\text { release of August } 6 \text {, } 1996 \text {, DOE says all work will be } \\
\text { complete by } 6 / 2000 \text {. Which is right? You need to be } \\
\text { consistent. I think you need to start your transfers } \\
\text { early in } 1999 \text {. }\end{array}$ & & $\begin{array}{l}\text { The schedule is a moving target, but the } \\
\text { baseline is still } 1 / 2000 \text { to } 12 / 2000 \text {. }\end{array}$ & \\
\hline 2 & $\begin{array}{l}\text { On CDR-008///Page } 2,7 \text { th para. Give a range of } \\
\text { shipment volumes expected and estimate the total } \\
\text { volume to be shipped for all of campaign. }\end{array}$ & & $\begin{array}{l}\text { This information can be found in WHC-SD-SNF- } \\
\text { FDC-004 and WHC-SD-SNF-DB-012. Shipment } \\
\text { size is expected to be } 3-6 \mathrm{~m}^{3} \text {. About } 60 \\
\text { shipments are currently anticipated. }\end{array}$ & \\
\hline 3 & $\begin{array}{l}\text { On CDR-008///Page } 4 \text {, sec. } 4.3 \text {, 2nd par. Add a } \\
\text { sentence saying that the floor of the basin will be } \\
\text { sloped so there will be a low point for pumping out } \\
\text { if there is a spill. Also in this par. it says that } \\
\text { the trailer will be } 30 \text { feet long. Yet drawings } \\
\text { H-14-100727 sh. } 2 \text { and H-14-100778 say } 40 \text { feet. Which } \\
\text { is right? I prefer the } 30 \text { feet. The shorter the } \\
\text { better for farm access. }\end{array}$ & & $\begin{array}{l}30 \mathrm{ft} \text { is correct. Drawings will be } \\
\text { corrected. }\end{array}$ & \\
\hline
\end{tabular}




\begin{tabular}{|c|c|c|c|c|c|}
\hline \multirow{2}{*}{\multicolumn{3}{|c|}{ REVIEW COMMENT RECORD (RCR) }} & $\begin{array}{l}\text { 1. Date } \\
09 / 23 / 96 \\
\end{array}$ & \multicolumn{2}{|l|}{ 2. Review No. } \\
\hline & & & $\begin{array}{r}\text { 3. Project No. } \\
\text { A. } 13 \\
\end{array}$ & \multicolumn{2}{|c|}{2 of 2} \\
\hline $\begin{array}{ll}12 . \\
\text { Item }\end{array}$ & $\begin{array}{l}\text { 13. Corment(s)/Discrepancy(s) (Provide technical justification for the } \\
\text { comment and detailed recormendation of the action required to correct/ } \\
\text { resolve the discrepancy/problem indicated.) }\end{array}$ & $\begin{array}{l}\text { 14. } \\
\text { Hold } \\
\text { Point }\end{array}$ & \multicolumn{2}{|c|}{ 15. Disposition (Provide justification if NOT accepted.) } & $\begin{array}{l}16 . \\
\text { Status }\end{array}$ \\
\hline 4 & $\begin{array}{l}\text { On CDR-008///Sec. } 4.4 .2 \text {, Ist Par., 3rd sentence. } \\
\text { Please reword to say minimal flushes will be used. } \\
\text { The } 3200 \text { gallons should be deleted. If you pick } \\
\text { anything, say } 1000 \text { gallons since we have water } \\
\text { trucks with that capacity. }\end{array}$ & & \multicolumn{2}{|c|}{$\begin{array}{l}\text { Conceptual estimate is based on twice the } \\
\text { maximum container volume. This doesn't need } \\
\text { to be available all at once, it just needs } \\
\text { to be available. This will be clarified in } \\
\text { the systems design description. }\end{array}$} & \\
\hline 5 & $\begin{array}{l}\text { DWG.H-14-100727, sh. } 2 \text { How does the hose reel connect } \\
\text { to transfer line to flush either the tank or } \\
\text { transfer line? How do you isolate one route while } \\
\text { you are flushing the other? I see the valves on the } \\
\text { pumpout line but no others. How are you assuring no } \\
\text { backflow in the flush system? Suggest you show a } \\
\text { piping schematic flow diagram of the flush system } \\
\text { showing valves, backflow, etc. This could be added } \\
\text { to H-14-100785. Need also to show flush line to hose } \\
\text { reel and valving and hose reel to the rest of the } \\
\text { system. Also, if you are going to pump the retention } \\
\text { basin, show the piping arrangement on this. }\end{array}$ & $Y$ & \multicolumn{2}{|c|}{$\begin{array}{l}\text { There is no longer a hose reel. There is } \\
\text { only one reoute, the flush water will be } \\
\text { routed through the Transport System and } \\
\text { transfer line. Details will be added to } \\
\text { drawings to depict sump pump and flush } 7 \text { ine } \\
\text { tie into transfer line. }\end{array}$} & \\
\hline 6 & $\begin{array}{l}\text { DWG.H-14-100727, Sh. } 3 \text { and } 5 \text {. These drawings show a } \\
\text { valve in the } 11 / 2 \text { inch pipe jumper. All the other } \\
\text { drawings do not. Which is right? I don } t \text { see the } \\
\text { value of having this valve. }\end{array}$ & & \multirow{2}{*}{\multicolumn{2}{|c|}{$\begin{array}{l}\text { Drawing } 100727 \text { is not correct. It will be } \\
\text { corrected. }\end{array}$}} & \\
\hline & & & & & \\
\hline
\end{tabular}




\begin{tabular}{|c|c|c|}
\hline & 1. Date & $\begin{array}{r}\text { 2. Review No. } \\
\text { TBD } \\
\end{array}$ \\
\hline REVIEW COMMENT RECORD (RCR) & $\begin{array}{r}\text { 3. Project No. } \\
\text { TBD }\end{array}$ & 4. Page \\
\hline
\end{tabular}

\begin{tabular}{l|l|l|l|l}
\hline 5. Document Number(s)/Iitle(s) & $\begin{array}{l}\text { 6. Program/Project/ } \\
\text { Building Number } \\
\text { K Basin }\end{array}$ & $\begin{array}{l}\text { 7. Reviewer } \\
\text { Craig Shaw }\end{array}$ & $\begin{array}{l}\text { 8. Organization/Group } \\
74 F 10 \text { TWRS DB Eq. } \\
\text { Sludge Receiving Station 90\% Design }\end{array}$ & $\begin{array}{l}\text { 200E M0 047 376- } \\
\text { Review }\end{array}$
\end{tabular}

17. Comment Submittal Approval:

Organization Manager (Optional)

10. Agreement with indicated comment disposition(s)

$$
\frac{\text { Curat } 5 \text { haur }}{\text { Reviewer/Poink of contact }}
$$

11. CLOSED

$\overline{\text { Date }}$

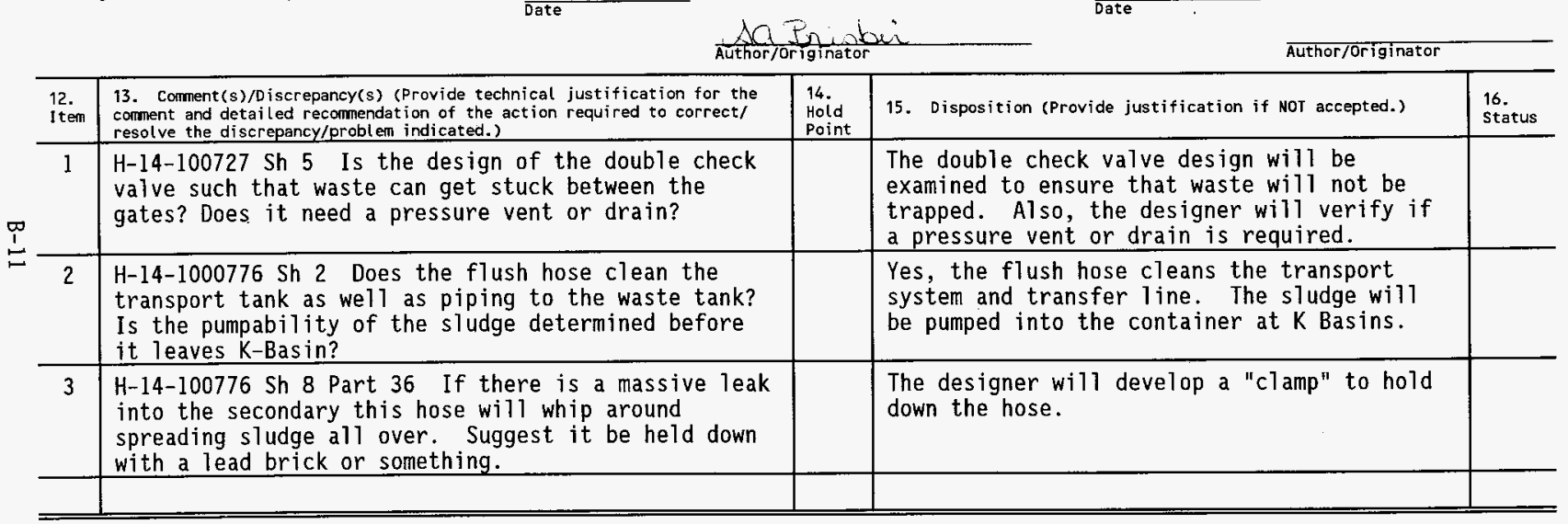




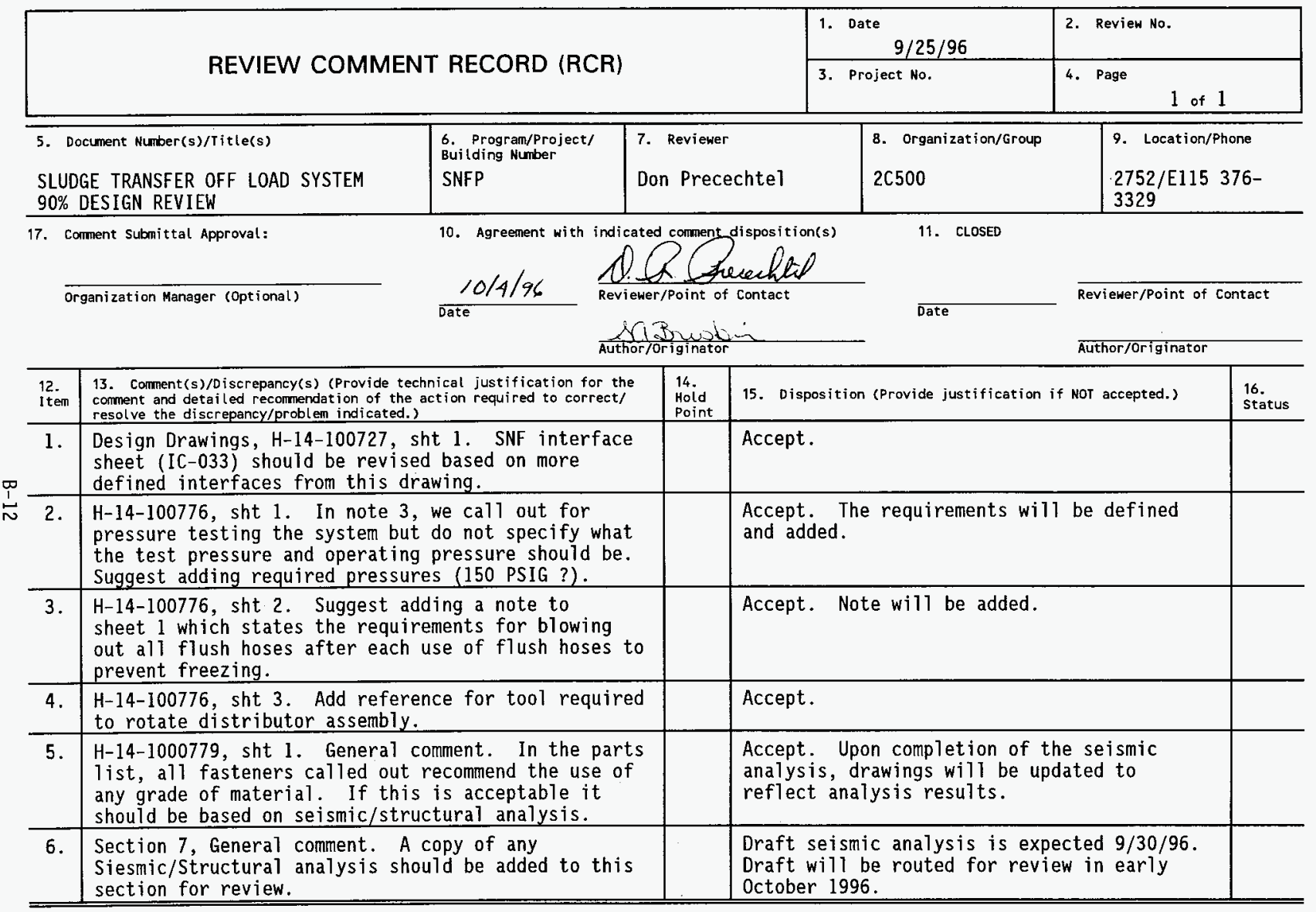




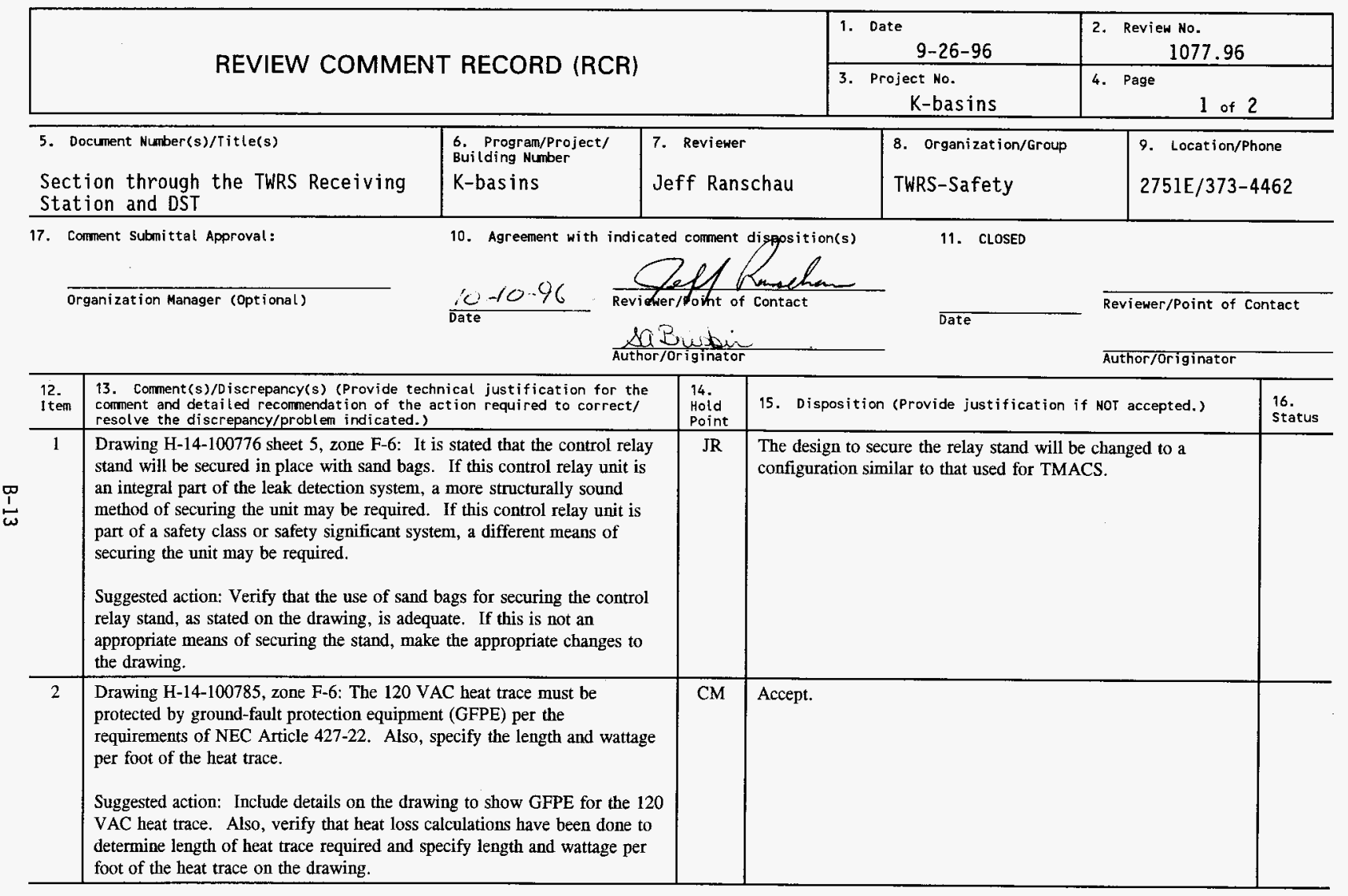




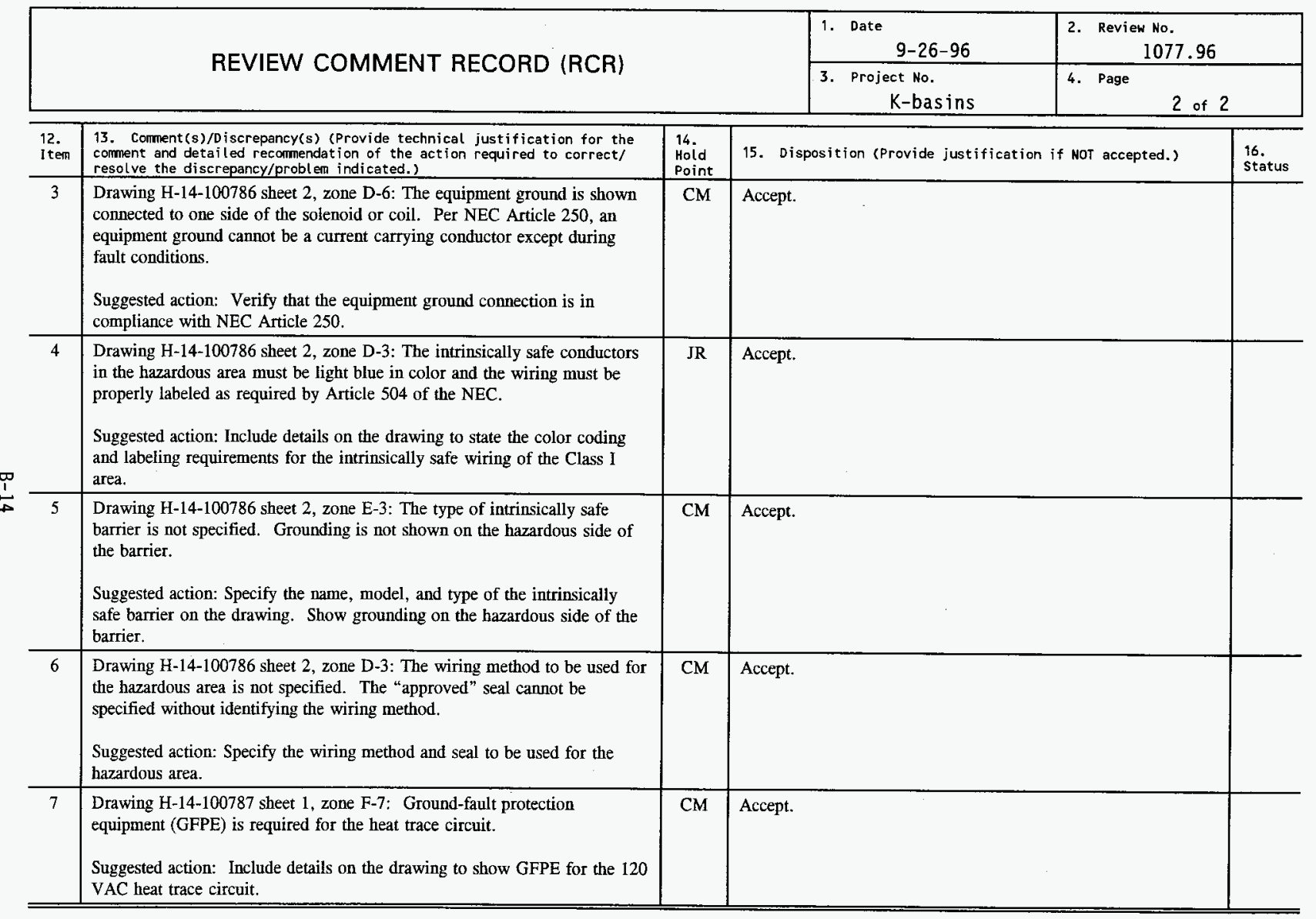


WHC-SD-SNF-DRR-010, Rev. 0

DON'T SAY IT --- Write It!

TO: D.H. Splett

S7-41

cc:
DATE: $9 / 24 / 96$

FROM: W.W. Wassberg X3-71

Telephone: $372-1958$

SUBJECT: Review or the $90 \%$ Design Review of the $\mathrm{K}$ Basin Sludge Receiving Station

Have reviewed the above document and found it to be in order except that several key items are waiting for the $100 \%$ design review. Many of the major ALARA issues still need to be completed.

If you have any questions please contact me. 
WHC-SD-SNF-DRR-010, Rev. 0

APPENDIX C--DESIGN REVIEW CHECKLIST 
WHC-SD-SNF-DRR-010, Rev. 0

Design Review Checklist (Page 1 of 9)

Document(s) Reviewed: Drawing Tree

Design Drawings

\begin{tabular}{|c|c|c|c|c|c|}
\hline \multirow{2}{*}{ A.13 } & \multirow{2}{*}{$\begin{array}{c}\begin{array}{c}\text { Sludge Process and Loadout } \\
\text { System }\end{array} \\
\text { Review Consideration }\end{array}$} & \multicolumn{3}{|c|}{ Design Phase } & \multirow{2}{*}{$\frac{\text { Cognizant Engineer }}{\text { Remarks }}$} \\
\hline & & Yes & No & NA & \\
\hline 1 & $\begin{array}{l}\text { Have assumptions necessary to } \\
\text { perform the design task been } \\
\text { adequately described and are } \\
\text { they reasonable? Where } \\
\text { necessary, have assumptions } \\
\text { been identified for } \\
\text { reverification when the design } \\
\text { task has been completed? }\end{array}$ & Yes & & & See RCR comments. \\
\hline 2 & $\begin{array}{l}\text { Have the appropriate Quality } \\
\text { Assurance requirements been } \\
\text { specified? }\end{array}$ & Yes & & & \\
\hline 3 & $\begin{array}{l}\text { Were sources of information } \\
\text { identified? }\end{array}$ & Yes & & & \\
\hline 4 & $\begin{array}{l}\text { Does the design meet the } \\
\text { established requirements or } \\
\text { design criteria? }\end{array}$ & Yes & & & See RCR comments. \\
\hline 5 & $\begin{array}{l}\text { Does the design meet } \\
\text { established requirements for } \\
\text { associated system physical and } \\
\text { functional interfaces? }\end{array}$ & Yes & & & \\
\hline 6 & $\begin{array}{l}\text { Have the interface } \\
\text { requirements with site } \\
\text { construction drawings been } \\
\text { clearly specified and are they } \\
\text { achievable? }\end{array}$ & Yes & & & See RCR comments. \\
\hline 7 & $\begin{array}{l}\text { Are there any interface } \\
\text { problems? }\end{array}$ & & No & & None identified. \\
\hline 8 & $\begin{array}{l}\text { Has appropriate consideration } \\
\text { been given to use of } \\
\text { standardized parts, materials } \\
\text { and processes, and have } \\
\text { engineering standards and } \\
\text { criteria been specified } \\
\text { properly in the design? }\end{array}$ & Yes & & & See RCR comments. \\
\hline
\end{tabular}


WHC-SD-SNF-DRR-010, ReV. 0

Design Review Checklist (Page 2 of 9 )

\begin{tabular}{|c|c|c|c|c|c|}
\hline \multirow{2}{*}{$\begin{array}{l}\text { A. } 13 \\
\text { Item }\end{array}$} & \multirow{2}{*}{$\begin{array}{c}\begin{array}{c}\text { Sludge Process and Loadout } \\
\text { System }\end{array} \\
\text { Review Consideration }\end{array}$} & \multicolumn{3}{|c|}{ Design Phase } & \multirow{2}{*}{\begin{tabular}{|c|} 
Cognizant Engineer \\
Remarks \\
\end{tabular}} \\
\hline & & Yes & No & NA & \\
\hline 9 & $\begin{array}{l}\text { Does the design represent the } \\
\text { simplest design consistent } \\
\text { with functional requirements } \\
\text { and expected service } \\
\text { conditions? }\end{array}$ & Yes & & & $\begin{array}{l}\text { Based on previous } \\
\text { designs. }\end{array}$ \\
\hline 10 & $\begin{array}{l}\text { Can the equipment be readily } \\
\text { assembled/disassembled as } \\
\text { designed? }\end{array}$ & Yes & & & \\
\hline 11 & $\begin{array}{l}\text { Does the design minimize } \\
\text { overall cost to the extent } \\
\text { practicable? }\end{array}$ & Yes & & & See RCR comments. \\
\hline 12 & $\begin{array}{l}\text { Has the cost estimate been } \\
\text { verified by an independent } \\
\text { reviewer? }\end{array}$ & Yes & & & \\
\hline 13 & $\begin{array}{l}\text { Are the specified materials } \\
\text { compatible with each other and } \\
\text { the environmental conditions } \\
\text { to which the material will be } \\
\text { exposed? }\end{array}$ & Yes & & & $\begin{array}{l}\text { Based on FDC } \\
\text { requirements using } \\
\text { proved designs. }\end{array}$ \\
\hline 14 & $\begin{array}{l}\text { Are the applicable codes, } \\
\text { standards and requirements, } \\
\text { including revisions, properly } \\
\text { identified and are their } \\
\text { design requirements provided } \\
\text { for? }\end{array}$ & Yes & & & See RCR comments. \\
\hline 15 & $\begin{array}{l}\text { Have modifications to } \\
\text { commercial grade items and any } \\
\text { associated verification } \\
\text { operations or tests been } \\
\text { appropriately documented? }\end{array}$ & & & NA & \\
\hline 16 & $\begin{array}{l}\text { Have qualified and certified } \\
\text { parts been specified? }\end{array}$ & Yes & & & $\begin{array}{l}\text { See RCR comments. } \\
\text { Will be completed } \\
\text { by final design } \\
\text { review. }\end{array}$ \\
\hline 17 & $\begin{array}{l}\text { Have available data on similar } \\
\text { designs been used? }\end{array}$ & Yes & & & \\
\hline
\end{tabular}


WHC-SD-SNF-DRR-010, Rev. 0

Design Review Checklist (Page 3 of 9)

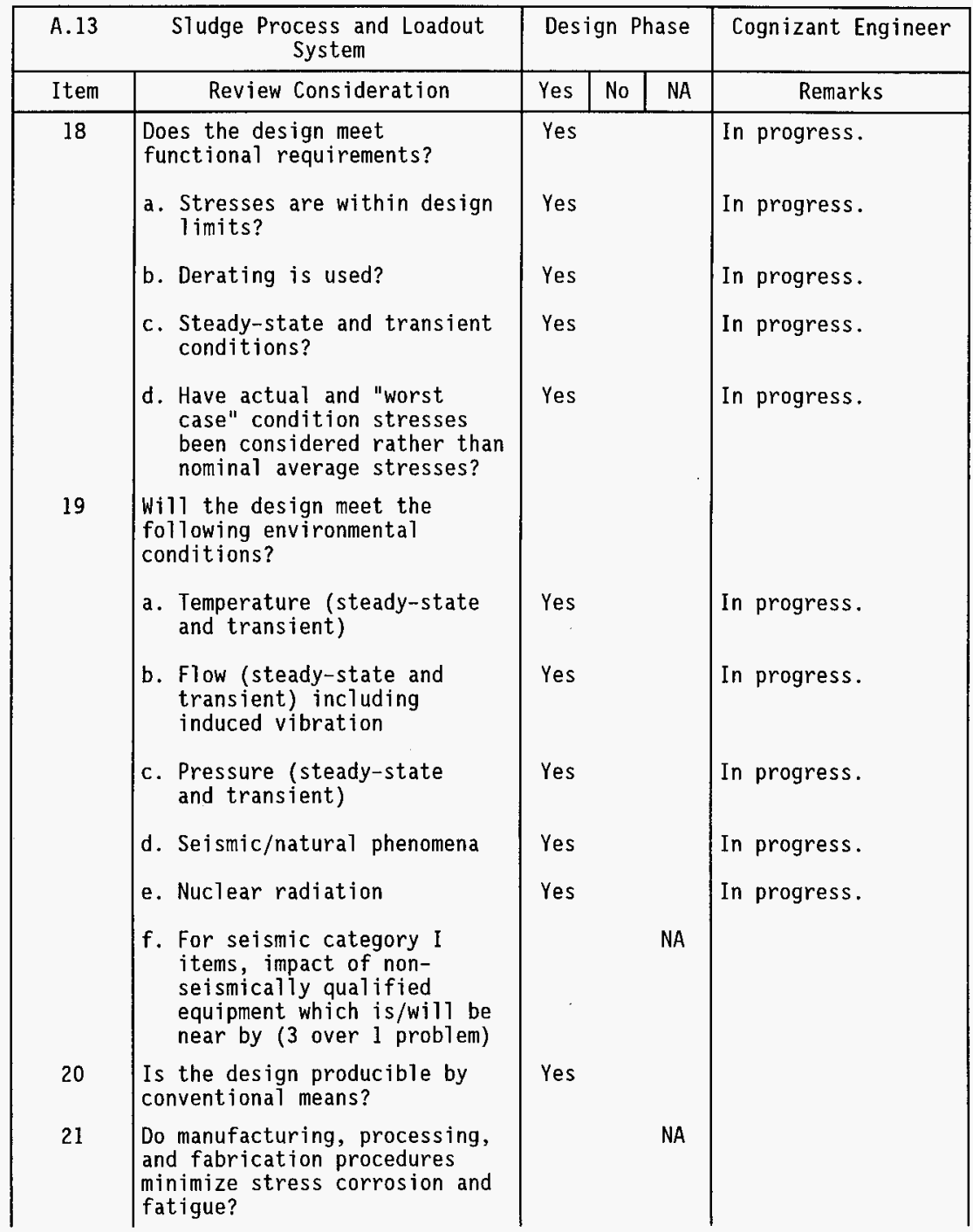


Design Review Checklist (Page 4 of 9)

\begin{tabular}{|c|c|c|c|c|c|}
\hline \multirow{2}{*}{$\begin{array}{l}\text { A. } 13 \\
\text { Item }\end{array}$} & \multirow{2}{*}{$\begin{array}{c}\begin{array}{c}\text { Sludge Process and Loadout } \\
\text { System }\end{array} \\
\text { Review Consideration }\end{array}$} & \multicolumn{3}{|c|}{ Design Phase } & \multirow{2}{*}{\begin{tabular}{|c|} 
Cognizant Engineer \\
Remarks
\end{tabular}} \\
\hline & & Yes & No & NA & \\
\hline 22 & $\begin{array}{l}\text { Are the specified construction } \\
\text { materials resistant to the } \\
\text { following as applicable: } \\
\text { a. Moisture } \\
\text { b. Oxygen } \\
\text { c. Acids } \\
\text { d. Salts } \\
\text { e. Radiation }\end{array}$ & $\begin{array}{l}\text { Yes } \\
\text { Yes } \\
\text { Yes } \\
\text { Yes }\end{array}$ & & $N A$ & \\
\hline 23 & $\begin{array}{l}\text { Do the clearances and } \\
\text { tolerances take into account } \\
\text { the effects of age and wear? }\end{array}$ & & & NA & \\
\hline 24 & $\begin{array}{l}\text { Are mechanical tolerances } \\
\text { within the limits of normal } \\
\text { shop practice? }\end{array}$ & Yes & & & \\
\hline 25 & $\begin{array}{l}\text { Are assembly clearances } \\
\text { adequate? }\end{array}$ & Yes & & & \\
\hline 26 & $\begin{array}{l}\text { Have allowable leakages been } \\
\text { specified? }\end{array}$ & Yes & & & $\begin{array}{l}\text { Designed for zero } \\
\text { leakage. }\end{array}$ \\
\hline 27 & $\begin{array}{l}\text { Have non-corrosive materials } \\
\text { been used where required? }\end{array}$ & Yes & & & \\
\hline 28 & $\begin{array}{l}\text { Does the design avoid any } \\
\text { materials unproven for use in } \\
\text { the anticipated environment? }\end{array}$ & Yes & & & \\
\hline 29 & $\begin{array}{l}\text { Can the assembly be stored for } \\
\text { extended periods of time } \\
\text { without degrading effects? }\end{array}$ & & & NA & \\
\hline 30 & $\begin{array}{l}\text { Has the design appropriately } \\
\text { considered maintenance, } \\
\text { operation and reliability, } \\
\text { including maintenance } \\
\text { procedures and techniques, } \\
\text { unique maintenance } \\
\text { requirements and frequencies? }\end{array}$ & & No & & $\begin{array}{l}\text { Will be addressed } \\
\text { prior to operation. }\end{array}$ \\
\hline 31 & $\begin{array}{l}\text { Are coatings (or finishes) } \\
\text { compatible with the expected } \\
\text { environment? With expected } \\
\text { usage? }\end{array}$ & Yes & & & \\
\hline
\end{tabular}


WHC-SD-SNF-DRR-010, Rev. 0

Design Review Checklist (Page 5 of 9)

\begin{tabular}{|c|c|c|c|c|c|}
\hline \multirow{2}{*}{ A. 13} & \multirow{2}{*}{$\begin{array}{c}\text { Sludge Process and Loadout } \\
\text { System } \\
\text { Review Consideration }\end{array}$} & \multicolumn{3}{|c|}{ Design Phase } & \multirow{2}{*}{$\begin{array}{c}\text { Cognizant Engineer } \\
\text { Remarks } \\
\end{array}$} \\
\hline & & Yes & No & NA & \\
\hline 32 & $\begin{array}{l}\text { Are surface finish } \\
\text { requirements the least } \\
\text { stringent possible? }\end{array}$ & & & NA & $\begin{array}{l}\text { This is not } N A \\
\text { Sunface finds } 15 \\
\text { lapontant to decon }\end{array}$ \\
\hline 33 & $\begin{array}{l}\text { Are required tolerances, } \\
\text { fabrication techniques, } \\
\text { processes, etc., consistent } \\
\text { with standard practices? }\end{array}$ & Yes & & & 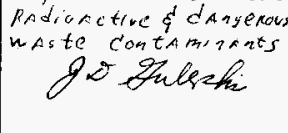 \\
\hline 34 & $\begin{array}{l}\text { Can the design and its parts } \\
\text { be easily inspected for } \\
\text { conformance to engineering } \\
\text { specifications? }\end{array}$ & Yes & & & \\
\hline 35 & $\begin{array}{l}\text { Has adequate accessibility } \\
\text { been provided for in-service } \\
\text { inspection? }\end{array}$ & Yes & & & \\
\hline 36 & $\begin{array}{l}\text { Does the design meet a11 } \\
\text { established safety } \\
\text { requirements? }\end{array}$ & Yes & & & In progress. \\
\hline 37 & $\begin{array}{l}\text { Has an acceptable level of } \\
\text { radiation exposure been } \\
\text { defined? }\end{array}$ & Yes & & & \\
\hline 38 & $\begin{array}{l}\text { Have personnel radiation } \\
\text { protection requirements been } \\
\text { considered and identified? }\end{array}$ & Yes & & & \\
\hline 39 & $\begin{array}{l}\text { Have nuclear criticality } \\
\text { safety considerations been } \\
\text { incorporated? }\end{array}$ & Yes & & & In progress. \\
\hline 40 & $\begin{array}{l}\text { Have necessary features been } \\
\text { provided to maintain personnel } \\
\text { radiation exposure as low as } \\
\text { reasonably achievable? }\end{array}$ & Yes & & & \\
\hline 41 & $\begin{array}{l}\text { Can the hardware be adequately } \\
\text { disposed of after use if it is } \\
\text { radiologically or chemically } \\
\text { contaminated? }\end{array}$ & Yes & & & 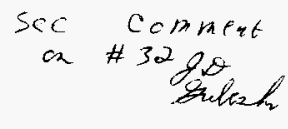 \\
\hline 42 & $\begin{array}{l}\text { Have requirements for } \\
\text { receiving and storing the } \\
\text { equipment item been defined? }\end{array}$ & & No & & \\
\hline
\end{tabular}


WHC-SD-SNF-DRR-010, Rev. 0

Design Review Checklist (Page 6 of 9)

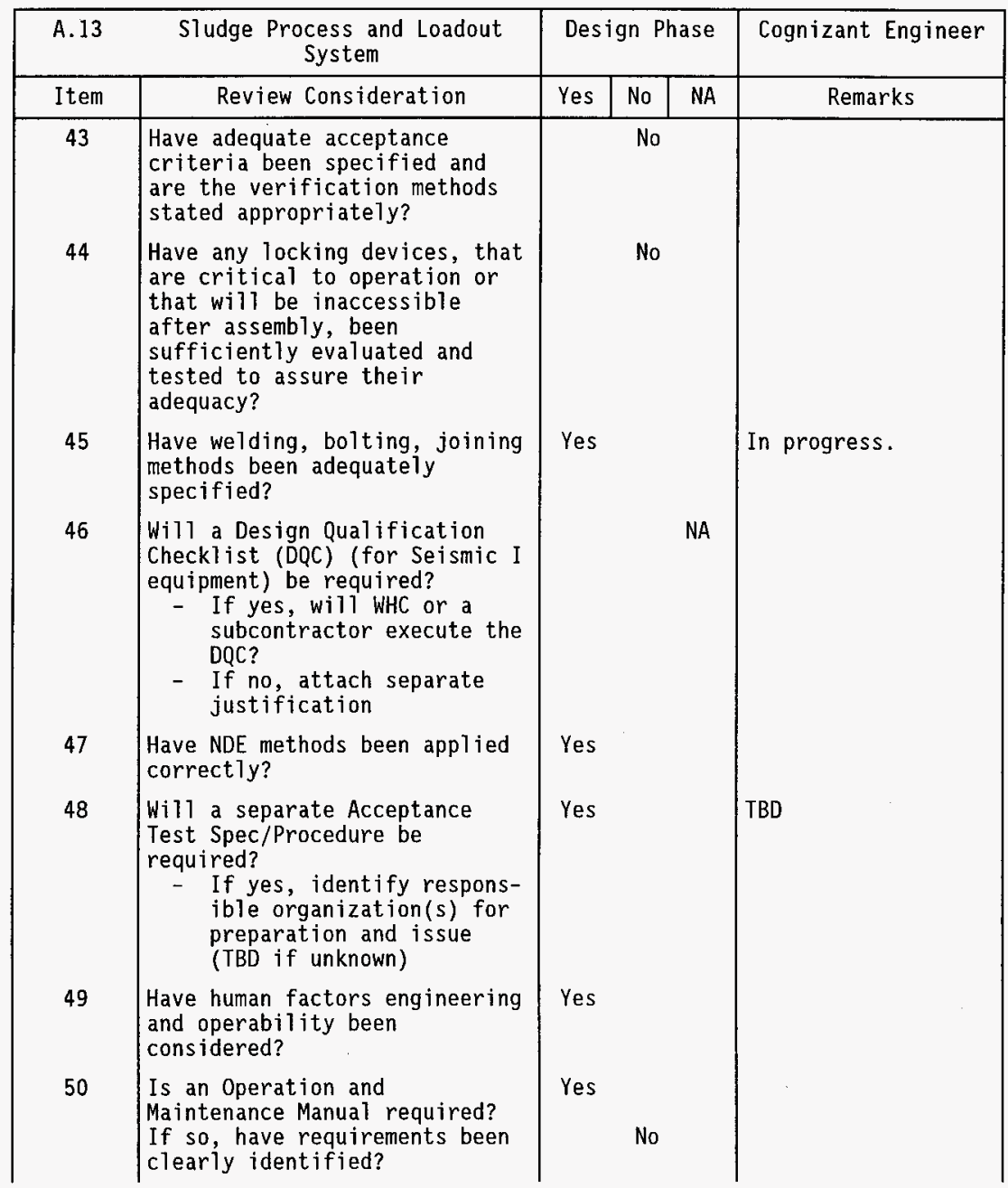


WHC-SD-SNF-DRR-010, Rev. 0

Design Review Checklist (Page 7 of 9)

\begin{tabular}{|c|c|c|c|c|c|}
\hline \multirow{2}{*}{$\begin{array}{l}\text { A.13 } \\
\text { Item }\end{array}$} & \multirow{2}{*}{$\begin{array}{c}\text { Sludge Process and Loadout } \\
\text { System }\end{array}$} & \multicolumn{3}{|c|}{ Design Phase } & \multirow{2}{*}{\begin{tabular}{|c|} 
Cognizant Engineer \\
Remarks
\end{tabular}} \\
\hline & & Yes & No & NA & \\
\hline 51 & $\begin{array}{l}\text { Are current operating } \\
\text { documents (procedures, } \\
\text { specifications, etc.) } \\
\text { appl icable to the design or } \\
\text { are changes necessary? }\end{array}$ & & No & & \\
\hline 52 & $\begin{array}{l}\text { Does the design use engineered } \\
\text { safety and operational } \\
\text { protections to avoid an } \\
\text { excessive risk-taking } \\
\text { dependence on administrative } \\
\text { infallibility? }\end{array}$ & Yes & & & \\
\hline 53 & $\begin{array}{l}\text { Are reliability requirements } \\
\text { specified? If so, does the } \\
\text { reliability analysis of the } \\
\text { design meet the specified } \\
\text { reliability requirements? }\end{array}$ & Yes & & NA & $\begin{array}{l}\text { Analysis not } \\
\text { required. }\end{array}$ \\
\hline 54 & $\begin{array}{l}\text { Have all credible non-standard } \\
\text { conditions been properly } \\
\text { considered? }\end{array}$ & Yes & & & In progress. \\
\hline 55 & $\begin{array}{l}\text { Is the equipment, system, or } \\
\text { facility operable? }\end{array}$ & & & NA & \\
\hline 56 & $\begin{array}{l}\text { Is the equipment design } \\
\text { adequate to implement the } \\
\text { proposed maintenance } \\
\text { philosophy? }\end{array}$ & Yes & & & \\
\hline 57 & $\begin{array}{l}\text { If any development work is } \\
\text { needed, has it been funded or } \\
\text { performed? }\end{array}$ & & & NA & \\
\hline 58 & $\begin{array}{l}\text { Has drawing traceability been } \\
\text { provided? }\end{array}$ & Yes & & & \\
\hline 59 & $\begin{array}{l}\text { Has the need for safety } \\
\text { analysis of this design been } \\
\text { determined by Safety? }\end{array}$ & Yes & & & \\
\hline 60 & $\begin{array}{l}\text { Is the equipment, system, or } \\
\text { facility covered by an } \\
\text { existing Safety Analysis } \\
\text { Report? If not, complete the } \\
\text { safety analysis in time to } \\
\text { incorporate findings of the } \\
\text { analyzed in the design. }\end{array}$ & & No & & In progress. \\
\hline
\end{tabular}


WHC-SD-SNF-DRR-010, Rev. 0

Design Review Checklist (Page 8 of 9)

\begin{tabular}{|c|c|c|c|c|c|}
\hline \multirow{2}{*}{ A. 13} & \multirow{2}{*}{$\begin{array}{c}\begin{array}{c}\text { Sludge Process and Loadout } \\
\text { System }\end{array} \\
\text { Review Consideration }\end{array}$} & \multicolumn{3}{|c|}{ Design Phase } & \multirow{2}{*}{\begin{tabular}{|c|} 
Cognizant Engineer \\
Remarks
\end{tabular}} \\
\hline & & Yes & No & NA & \\
\hline 61 & $\begin{array}{l}\text { Does the design match the } \\
\text { intended (and possible } \\
\text { abnormal) methods of operation } \\
\text { of the system or facility? }\end{array}$ & Yes & & & \\
\hline 62 & $\begin{array}{l}\text { Do the reliability, } \\
\text { availability, and } \\
\text { maintainability (RAM) analyses } \\
\text { of the design support the RAM } \\
\text { requirements? }\end{array}$ & & & NA & \\
\hline 63 & $\begin{array}{l}\text { Is a single point failure } \\
\text { analysis required? }\end{array}$ & & & & $\begin{array}{l}\text { TBD per safety } \\
\text { analysis }\end{array}$ \\
\hline 64 & $\begin{array}{l}\text { Are a1l indication lights and } \\
\text { electrical control considered } \\
\text { fail-safe? }\end{array}$ & & & NA & \\
\hline 65 & $\begin{array}{l}\text { Do the design media, format, } \\
\text { content, reproducibility, and } \\
\text { quality comply with all } \\
\text { applicable requirements } \\
\text { (including Hanford Plant } \\
\text { Standards and referenced codes } \\
\text { and standards)? Are the } \\
\text { drawings structured to meet } \\
\text { the needs of users after } \\
\text { project completion? }\end{array}$ & Yes & & & See RCR comments. \\
\hline 66 & $\begin{array}{l}\text { Have availability of power } \\
\text { requirements for the project } \\
\text { been verified? }\end{array}$ & Yes & & & In progress. \\
\hline 67 & $\begin{array}{l}\text { Have requirements for } \\
\text { providing as-built drawings } \\
\text { been specified? }\end{array}$ & Yes & & & $\begin{array}{l}\text { Per EP } \\
\text { requirements. }\end{array}$ \\
\hline 68 & $\begin{array}{l}\text { Is the design in compliance } \\
\text { with applicable regulatory } \\
\text { requirements and/or WHC } \\
\text { regulatory commitments? }\end{array}$ & Yes & & & In progress. \\
\hline 69 & $\begin{array}{l}\text { Are design tolerances } \\
\text { appropriate and applied in a } \\
\text { cost-effective manner and are } \\
\text { standard materials and } \\
\text { material sizes used where } \\
\text { practicable? }\end{array}$ & Yes & & & \\
\hline
\end{tabular}


WHC-SD-SNF-DRR-010, Rev. 0

Design Review Checklist (Page 9 of 9)

\begin{tabular}{|c|c|c|c|c|c|}
\hline A.13 & \multicolumn{1}{|c|}{$\begin{array}{c}\text { Sludge Process and Loadout } \\
\text { System }\end{array}$} & \multicolumn{2}{|c|}{ Design Phase } & Cognizant Engineer \\
\hline Item & \multicolumn{1}{|c|}{ Review Consideration } & Yes & No & NA & Remarks \\
\hline 70 & $\begin{array}{l}\text { Is a11 computer software and } \\
\text { data properly identified and } \\
\text { controlled? }\end{array}$ & \multicolumn{2}{|l|}{ Yes } & \\
\hline
\end{tabular}




\begin{tabular}{|c|c|c|c|c|c|}
\hline \multicolumn{6}{|c|}{ DISTRIBUTION SHEET } \\
\hline To & \multirow{2}{*}{\multicolumn{3}{|c|}{$\begin{array}{l}\text { From } \\
\text { Facility Cleanup Projects }\end{array}$}} & \multicolumn{2}{|c|}{ Page 1 of 1} \\
\hline Distribution & & & & \multicolumn{2}{|c|}{$\begin{array}{l}\text { Date October 14, } \\
1996\end{array}$} \\
\hline \multicolumn{4}{|l|}{$\begin{array}{l}\text { Project Title/Work Order } \\
\text { Sludge Receiving Station }\end{array}$} & \multicolumn{2}{|c|}{ EDT No. 619350} \\
\hline Sludge Receiving Station & n Review Rep & & & \multicolumn{2}{|c|}{ ECN No. NA } \\
\hline Name & MSIN & $\begin{array}{c}\text { Text } \\
\text { With All } \\
\text { Attach. }\end{array}$ & Text Only & $\begin{array}{c}\text { Attach./ } \\
\text { Appendix } \\
\text { Only }\end{array}$ & $\begin{array}{l}\text { EDT/ECN } \\
\text { Only }\end{array}$ \\
\hline $\begin{array}{l}\text { C. J. Alderman } \\
\text { V. C. Boyles } \\
\text { S. A. Brisbin } \\
\text { K. G. Carothers } \\
\text { D. W. Crass } \\
\text { J. D. Guberski } \\
\text { G. S. Hunacek } \\
\text { R. J. Lodwick } \\
\text { F. W. Moore } \\
\text { F. J. Muller } \\
\text { K. L. Pearce } \\
\text { D. R. Precechtel } \\
\text { C. A. Sams } \\
\text { C. P. Shaw } \\
\text { J. P. Sloughter } \\
\text { P. L. Smith } \\
\text { J. R. Thielges } \\
\text { C. A. Thompson } \\
\text { A. F. Wellner } \\
\text { H. H. Ziada } \\
\text { K Basin Project File/A.13 } \\
\text { SNF Project File } \\
\text { Central Files } \\
\end{array}$ & $\begin{array}{l}\text { R3-48 } \\
\text { R1-43 } \\
\text { R3-48 } \\
\text { R1-51 } \\
\text { H5-68 } \\
\text { R1-51 } \\
\text { X3-79 } \\
\text { X3-78 } \\
\text { X3-85 } \\
\text { X3-85 } \\
\text { R3-48 } \\
\text { R3-48 } \\
\text { S5-13 } \\
\text { S2-24 } \\
\text { R2-54 } \\
\text { R3-08 } \\
\text { L6-38 } \\
\text { X3-85 } \\
\text { H5-70 } \\
\text { R1-56 } \\
\text { X3-85 } \\
\text { R3-11 } \\
\text { A3-88 }\end{array}$ & & & & \\
\hline
\end{tabular}

